\title{
PREVENTIVE TREATMENT OF DRYING CHAMBER WITH UV RADIATION AND OZONIZATION FOR PROTECTION AGAINST SPOILAGE OF RAW SMOKED SAUSAGES
}

\author{
A.M. Abdullaeva', L.P. Blinkova², I.G. Seryogin³, D.I. Udavliev', S.S. Shikhov', Yu.D. Pakhomov² \\ ${ }^{1}$ Moscow State University of Food Industry, Moscow, Russia \\ ${ }^{2}$ I.I. Mechnikov Research Institute for Vaccines and Sera, Moscow, Russia \\ 3K.A. Timiryazev Russian State Agrarian University, Moscow, Russia
}

\begin{abstract}
In this work, we present data on efficiency of UV irradiation and its combination with ozone treatment for disinfection of drying chambers of dry smoked sausages that are subject to molding during storage. Biocide effect was created using UV irradiator OBN-15O and ozonator-irradiator OZUF. A study of the total number of microorganisms and molds before and after inactivation was conducted with exposition times of 30 , 60 and 90 minutes. Biocide effect was stronger with longer exposition times. Molds were more resistant to the effect of irradiators than bacteria. As a result of 9o-minute irradiation with OZUF apparatus we achieved death of approximately $90 \%$ of microbiota and more than $80 \%$ of molds. Shelf-life of dry smoked sausage without molding increased.
\end{abstract}

Keywords: Protection, drying chamber, sausage, ozone, shelf-life, UV irradiation

\section{INTRODUCTION}

In recent years growing urgency for meat industry is a topic of increasing microbiological effectiveness of controlling food products and efficiency of their antimicrobial protection. This is associated with the fact that in Russia and other countries a number of diseases emerge (salmonellosis, dysentery, toxicosis, etc.), which are associated with the consumption of meat products infected with various microorganisms $[1,2]$.

The epidemiological safety and quality of meat depends on factors such as the absence of infection of a slaughter animal, its maintenance conditions, transportation of meat, the technology of primary processing, as well as further processes of heat treatment and storage. If the storage conditions of meat and meat products are affected, then microbiological spoilage occurs in the form of rotting, mucus, mold, pigmentation, etc. On the surface of meat and meat products, putrefactive, lactic acid, butyric acid bacteria, micrococci, mold fungi, yeast and other microorganisms usually appear. These processes very often cause food poisoning [2, 3]. The list of microorganisms that cause damage is quite large. Gram-negative rods are known to be among the bacteria that cause spoilage, for example, Pseudomonas, as well as gram-positive spore-forming bacteria, such as Bacillus, Clostridium. In addition, there is a large group of bacteria from the family Enterobacteriaceae. This group is also used as an indicator of quality and nutritional risk. The surfaces of long-stored products are often colonized by mold fungi from the genera Penicillium, Aspergillus, Cladosporium, etc. [4, 5, 6,]. In order to extend the shelf life and prevent rapid spoilage of meat and meat products, highly efficient technologies are being created and various long-term storage methods based on the use of vacuum, modified gas atmosphere, preservatives of various nature, physical and chemical factors, etc. are used [7, 8]. Among all types of meat after the ban on importing pork into the Russian Federation since 2014, the share of consumption of poultry meat (chicken, turkey, goose, duck, guinea fowl) and their products has increased significantly. However, one of the significant problems of the poultry industry is to ensure the longest shelf-life for products of different product assortment. Thus, during storage, the stability of the properties of sausages containing chicken meat depends mainly on how dehydrated they are. Therefore, after smoking, sausages are dried. To preserve the qualities inherent in raw smoked sausage of a certain sort, the moisture content in the finished product is set at a level of $25-30 \%$. Drying of smoked sausages is carried out at a temperature of $12{ }^{\circ} \mathrm{C}$ and a relative humidity of $75 \%$. Duration of drying is 25-90 days.

The purpose of our study was to assess the possible use of radiant energy using UV irradiators, as well as in combination with ozonation for disinfection of drying chambers for smoked sausages of long-term storage.

*asiat29@mail.ru 
A.M. Abdullaeva et al., Preventive treatment of drying chamber..., RAP Conf. Proc., vol. 4, 2019, 206-211

\section{MATERIALS AND METHODS}

In our experiments, we used the drying chamber with a volume of $200 \mathrm{~m}^{3}$, equipped with $\mathrm{OBN}-150 \mathrm{UV}$ irradiators with two sources of irradiation of $30 \mathrm{~W}$ each, mounted on the walls, or UV irradiators with OZUF $40 \mathrm{~W}$ ozonizers. OZUF ozonizer is a recirculator, which can disinfect air in the "stagnant zones" of the room. Its UV lamp is in a closed housing with a fan that drives the air around the lamp and disinfects it with UV rays and ozone. This eliminates the undesirable oxidation of fats on the sausage surface. The greatest bactericidal action against microorganisms has a spectrum of rays of $240-280 \mathrm{~nm}$ [9].

Drying chambers had air conditioners which regulated levels of temperature and humidity. The operation of air conditioners was additionally controlled by psychrometers and thermometers. Irradiation was carried out in the dark for 30,60 and 90 minutes. Sausages for drying were placed in tiers in several rows, so as to ensure free air circulation between sausage loaves of the same size.

To study the effect of UV irradiation on the ability to inactivate the microbiota of the chamber, raw smoked sausages were used, which have in its composition minced chicken. The determination of the total number of microorganisms and mold fungi in
$1 \mathrm{~m}^{3}$ of the chamber was carried out after taking air samples using a sampling device (PU-1B) (Russia) and taking into account the grown colonies $\left(\mathrm{CFU} / \mathrm{m}^{3}\right)$ on Petri dishes with nutrient agar [10]. Samples through PU-1B were taken through conical nozzles with many tips and holes, under which Petri dishes were placed with meat-peptone agar. Jets of air from the nozzle containing the microbiota, falling on the surface of the nutrient medium, infected it. After 24 hours of incubation at $37^{\circ} \mathrm{C}$, the grown bacteria were taken into account, and after 3-4 days - the mold fungi. Quantitative indices of the total number of microorganisms and mold fungi were calculated for 1 $\mathrm{m}^{3}$ of air [10]. Statistical data processing was performed using parametric criteria: arithmetic average (X), its error (m) and confidence interval fluctuations in arithmetic average value (I95) for reliability $(\mathrm{p} \leq 0.05)$.

\section{RESULTS}

Experimental results after a 30-minute disinfection are presented in Table 1 and 2, in which indices of the total number of microorganisms (CFU / $\left.\mathrm{m}^{3}\right)$ and mold colonies are given.

Table 1. The results of the study of the bactericidal and fungicidal properties of the ultraviolet irradiator $\mathrm{OBN}-15 \mathrm{O}$ after treatment of the air in the drying chamber for 30 minutes

\begin{tabular}{|c|c|c|c|c|}
\hline \multirow{2}{*}{\begin{tabular}{c} 
No of $\begin{array}{c}\text { No } \\
\text { the } \\
\text { Petri } \\
\text { dish }\end{array}$ \\
\cline { 2 - 5 }
\end{tabular}} & \multicolumn{3}{|c|}{ Before treatment } & \multicolumn{2}{c|}{ After treatment } \\
\cline { 2 - 5 } & total microorganisms & of which molds & total microorganisms & of which molds \\
\hline 1 & $2.67 \times 10^{3}$ & $0.933 \times 10^{3}$ & $2.00 \times 10^{3}$ & $0.800 \times 10^{3}$ \\
\hline 2 & $2.53 \times 10^{3}$ & $0.667 \times 10^{3}$ & $1.73 \times 10^{3}$ & $0.667 \times 10^{3}$ \\
\hline 3 & $2.40 \times 10^{3}$ & $0.800 \times 10^{3}$ & $1.87 \times 10^{3}$ & $0.667 \times 10^{3}$ \\
\hline 4 & $2.53 \times 10^{3}$ & $0.933 \times 10^{3}$ & $2.00 \times 10^{3}$ & $0.800 \times 10^{3}$ \\
\hline 5 & $2.27 \times 10^{3}$ & $0.933 \times 10^{3}$ & $2.00 \times 10^{3}$ & $0.933 \times 10^{3}$ \\
\hline 6 & $2.40 \times 10^{3}$ & $0.800 \times 10^{3}$ & $1.87 \times 10^{3}$ & $0.800 \times 10^{3}$ \\
\hline 7 & $2.40 \times 10^{3}$ & $0.667 \times 10^{3}$ & $1.73 \times 10^{3}$ & $0.533 \times 10^{3}$ \\
\hline 8 & $2.67 \times 10^{3}$ & $0.800 \times 10^{3}$ & $1.73 \times 10^{3}$ & $0.667 \times 10^{3}$ \\
\hline 9 & $2.53 \times 10^{3}$ & $0.800 \times 10^{3}$ & $1.87 \times 10^{3}$ & $0.800 \times 10^{3}$ \\
\hline 10 & $2.27 \times 10^{3}$ & $0.933 \times 10^{3}$ & $2.00 \times 10^{3}$ & $0.800 \times 10^{3}$ \\
\hline $\mathrm{X} \pm \mathrm{m}$ & $(2.47 \pm 0.043) \times 10^{3}$ & $(0.827 \pm 0.031) \times 10^{3}$ & $(1.88 \pm 0.035) \times 10^{3}$ & $(0.747 \pm 0.034) \times 10^{3}$ \\
\hline $\mathrm{X} \pm \mathrm{I}_{95}$ & $(2.47 \pm 0.100) \times 10^{3}$ & $(0.827 \pm 0.069) \times 10^{3}$ & $(1.88 \pm 0.078) \times 10^{3}$ & $(0.747 \pm 0.076) \times 10^{3}$ \\
\hline
\end{tabular}

Table 2. The results of the study of the bactericidal and fungicidal properties of the ultraviolet irradiator and ozonizer OZUF after treatment of the air in the drying chamber for 30 minutes

\begin{tabular}{|c|c|c|c|c|}
\hline \multirow{3}{*}{$\begin{array}{l}\text { № of } \\
\text { the } \\
\text { Petri } \\
\text { dish }\end{array}$} & \multicolumn{4}{|c|}{ Numbers of colonies of microbes and molds in $1 \mathrm{~m}^{3}(\mathrm{CFU} / \mathrm{ml})$} \\
\hline & \multicolumn{2}{|c|}{ before treatment } & \multicolumn{2}{|c|}{ after treatment } \\
\hline & total microorganisms & of which molds & total microorganisms & of which molds \\
\hline 1 & $2.40 \times 10^{3}$ & $0.933 \times 10^{3}$ & $0.667 \times 10^{3}$ & $0.533 \times 10^{3}$ \\
\hline 2 & $2.53 \times 10^{3}$ & $0.667 \times 10^{3}$ & $0.800 \times 10^{3}$ & $0.400 \times 10^{3}$ \\
\hline 3 & $2.40 \times 10^{3}$ & $0.800 \times 10^{3}$ & $0.800 \times 10^{3}$ & $0.533 \times 10^{3}$ \\
\hline 4 & $2.67 \times 10^{3}$ & $0.800 \times 10^{3}$ & $0.933 \times 10^{3}$ & $0.400 \times 10^{3}$ \\
\hline 5 & $2.53 \times 10^{3}$ & $0.933 \times 10^{3}$ & $0.933 \times 10^{3}$ & $0.533 \times 10^{3}$ \\
\hline 6 & $2.67 \times 10^{3}$ & $0.933 \times 10^{3}$ & $0.667 \times 10^{3}$ & $0.667 \times 10^{3}$ \\
\hline 7 & $2.40 \times 10^{3}$ & $0.667 \times 10^{3}$ & $0.800 \times 10^{3}$ & $0.400 \times 10^{3}$ \\
\hline 8 & $2.27 \times 10^{3}$ & $0.800 \times 10^{3}$ & $0.800 \times 10^{3}$ & $0.533 \times 10^{3}$ \\
\hline 9 & $2.40 \times 10^{3}$ & $0.800 \times 10^{3}$ & $0.933 \times 10^{3}$ & $0.533 \times 10^{3}$ \\
\hline 10 & $2.53 \times 10^{3}$ & $0.667 \times 10^{3}$ & $0.667 \times 10^{3}$ & $0.667 \times 10^{3}$ \\
\hline $\mathrm{X} \pm \mathrm{m}$ & $(2.48 \pm 0.039) \times 10^{3}$ & $(0.800 \pm 0.033) \times 10^{3}$ & $(0.800 \pm 0.033) \times 10^{3}$ & $(0.520 \pm 0.030) \times 10^{3}$ \\
\hline $\mathrm{X} \pm \mathrm{I}_{95}$ & $(2.48 \pm 0.087) \times 10^{3}$ & $(0.800 \pm 0.074) \times 10^{3}$ & $(0.800 \pm 0.074) \times 10^{3}$ & $(0.520 \pm 0.067) \times 10^{3}$ \\
\hline
\end{tabular}


As follows from Table 1, prior to UV treatment with OBN-150, the number of mold colonies was $(0.827 \pm 0.069) \times 10^{3}$, which was $33 \%$ of the total number of microorganisms in $1 \mathrm{~m}^{3}$ of air $(2.47 \pm .0 .100) \times 10^{3}$. After treatment, this value was about $40 \%(0.747 \pm 0.076) \times 10^{3}$, i.e. the amount of mold, which is more resistant to UV radiation, has slightly increased in relation to the remaining total number of microbes $(1.88 \pm 0.078) \times 10^{3}$. Disinfection for 30 minutes using the $\mathrm{OBN}-150$ device reduced the total number of microorganisms by 1.3 times, and the amount of mold decreased 1.1 times. Under the effect of irradiation, about $24 \%$ of the number of all microorganisms and about $10 \%$ of mold fungi died (Table 7). With a similar conduct of air disinfection using an ozonizer-irradiator OZUF within 30 minutes revealed a decrease in the total number of microorganisms after exposure by 3.1 times. However, due to the fungicidal action after the combined inactivation of microorganisms by UV rays and ozone, the number of mold fungi decreased only 1.5 times. The amount of mold before treatment was in the association with the microbiota $32 \%$, and after $65 \%$, i.e. with a decrease in the population of all microorganisms, mold fungi dominated again. Therefore, after using the OZUF for 30 minutes, there was a higher total biocidal and a separate fungicidal effect (Table 7) in the air after treatment of the drying chambers $(67.7 \%$ and $35 \%)$ than in the same time mode with the irradiator OBN -150 (23.9\% and 9.7\%) This difference in performance is statistically significant $(\mathrm{p}<0.05)$. The data also indicate the statistical significance of differences in the viability of microorganisms and mold fungi before and after a 30-minute exposure (both using OBN-15O and OZUF) (Table 7). Comparison of the decline in the number of all microorganisms and mold fungi with a 60-minute air treatment in the drying chamber showed (Table 3) that for OBN-150 the disinfecting effect led to a decrease in the average number of all microorganisms by 3.2 times: $(2.19 \pm 0.096) \times 10^{3}$ compared to $(0.693 \pm 0.091) \times 10^{3}$, and the number of mold fungi by 1.2 times: $(1.13 \pm 0.105) \times 10^{3}$ compared to $(0.920 \pm 0.098) \times 10^{3}$.

Table 3. The results of the study of the bactericidal and fungicidal properties of the ultraviolet irradiator OBN-15O after treatment of the air in the drying chamber for 60 minutes

\begin{tabular}{|c|c|c|c|c|}
\hline \multirow{2}{*}{\begin{tabular}{c} 
No of $\begin{array}{c}\text { the } \\
\text { Petri } \\
\text { dish }\end{array}$ \\
\cline { 2 - 5 }
\end{tabular}} & \multicolumn{3}{|c|}{ Defore treatment } & \multicolumn{2}{c|}{ after treatment } \\
\cline { 2 - 5 } & total microorganisms & of which molds & total microorganisms & of which molds \\
\hline 1 & $2.27 \times 10^{3}$ & $1.20 \times 10^{3}$ & $0.533 \times 10^{3}$ & $0.667 \times 10^{3}$ \\
\hline 2 & $2.13 \times 10^{3}$ & $0.933 \times 10^{3}$ & $0.533 \times 10^{3}$ & $0.800 \times 10^{3}$ \\
\hline 3 & $2.13 \times 10^{3}$ & $1.07 \times 10^{3}$ & $0.667 \times 10^{3}$ & $0.800 \times 10^{3}$ \\
\hline 4 & $2.40 \times 10^{3}$ & $0.933 \times 10^{3}$ & $0.667 \times 10^{3}$ & $0.933^{3} 0^{3}$ \\
\hline 5 & $2.13 \times 10^{3}$ & $0.933 \times 10^{3}$ & $0.800 \times 10^{3}$ & $1.07 \times 10^{3}$ \\
\hline 6 & $2.00 \times 10^{3}$ & $1.33 \times 10^{3}$ & $0.800 \times 10^{3}$ & $1.07 \times 10^{3}$ \\
\hline 7 & $2.00 \times 10^{3}$ & $1.20 \times 10^{3}$ & $0.933 \times 10^{3}$ & $0.933 \times 10^{3}$ \\
\hline 8 & $2.40 \times 10^{3}$ & $1.33 \times 10^{3}$ & $0.800 \times 10^{3}$ & $0.800 \times 10^{3}$ \\
\hline 9 & $2.27 \times 10^{3}$ & $1.20 \times 10^{3}$ & $0.667 \times 10^{3}$ & $1.07 \times 10^{3}$ \\
\hline 10 & $2.13 \times 10^{3}$ & $1.20 \times 10^{3}$ & $0.533 \times 10^{3}$ & $1.07 \times 10^{3}$ \\
\hline $\mathrm{X} \pm \mathrm{m}$ & $(2.19 \pm 0.043) \times 10^{3}$ & $(1.13 \pm 0.047) \times 10^{3}$ & $(0.693 \pm 0.041) \times 10^{3}$ & $(0.920 \pm 0.044) \times 10^{3}$ \\
\hline $\mathrm{X} \pm \mathrm{I}_{95}$ & $(2.19 \pm 0.096) \times 10^{3}$ & $(1.13 \pm 0.105) \times 10^{3}$ & $(0.693 \pm 0.091) \times 10^{3}$ & $(0.920 \pm 0.098) \times 10^{3}$ \\
\hline
\end{tabular}

Table 4. The results of the study of the bactericidal and fungicidal properties of the ultraviolet irradiator and ozonizer OZUF after treatment of the air in the drying chamber for 60 minutes

\begin{tabular}{|c|c|c|c|c|}
\hline \multirow{2}{*}{$\begin{array}{c}\text { No of } \\
\text { the }\end{array}$} & \multicolumn{3}{|c|}{ Numbers of colonies of microbes and molds in $1 \mathrm{~m}^{3}(\mathrm{CFU} / \mathrm{ml})$} \\
\cline { 2 - 5 } $\begin{array}{c}\text { Petri } \\
\text { dish }\end{array}$ & \multicolumn{2}{|c|}{ before treatment } & \multicolumn{2}{c|}{ after treatment } \\
\cline { 2 - 5 } & total microorganisms & of which molds & total microorganisms & of which molds \\
\hline 1 & $2.13 \times 10^{3}$ & $1.33 \times 10^{3}$ & $0.667 \times 10^{3}$ & $0.267 \times 10^{3}$ \\
\hline 2 & $2.4 \times 10^{3}$ & $1.47 \times 10^{3}$ & $0.400 \times 10^{3}$ & $0.267 \times 10^{3}$ \\
\hline 3 & $2.13 \times 10^{3}$ & $1.33 \times 10^{3}$ & $0.400 \times 10^{3}$ & $0.400 \times 10^{3}$ \\
\hline 4 & $2.27 \times 10^{3}$ & $1.2 \times 10^{3}$ & $0.667 \times 10^{3}$ & $0.267 \times 10^{3}$ \\
\hline 5 & $2.27 \times 10^{3}$ & $1.2 \times 10^{3}$ & $0.533 \times 10^{3}$ & $0.400 \times 10^{3}$ \\
\hline 6 & $2.4 \times 10^{3}$ & $1.07 \times 10^{3}$ & $0.533 \times 10^{3}$ & $0.267 \times 10^{3}$ \\
\hline 7 & $2.0 \times 10^{3}$ & $1.33 \times 10^{3}$ & $0.400 \times 10^{3}$ & $0.267 \times 10^{3}$ \\
\hline 8 & $2.13 \times 10^{3}$ & $1.2 \times 10^{3}$ & $0.267 \times 10^{3}$ & $0.400 \times 10^{3}$ \\
\hline 9 & $2.53 \times 10^{3}$ & $1.33 \times 10^{3}$ & $0.533 \times 10^{3}$ & $0.267 \times 10^{3}$ \\
\hline 10 & $2.27 \times 10^{3}$ & $1.47 \times 10^{3}$ & $0.400 \times 10^{3}$ & $0.267 \times 10^{3}$ \\
\hline $\mathrm{X} \pm \mathrm{m}$ & $(2.25 \pm 0.048) \times 10^{3}$ & $(1.29 \pm 0.038) \times 10^{3}$ & $(0.480 \pm 0.039) \times 10^{3}$ & $(0.307 \pm 0.019) \times 10^{3}$ \\
\hline $\mathrm{X} \pm \mathrm{I}_{95}$ & $(2.25 \pm 0.107) \times 10^{3}$ & $(1.29 \pm 0.085) \times 10^{3}$ & $(0.480 \pm 0.087) \times 10^{3}$ & $(0.307 \pm 0.042) \times 10^{3}$ \\
\hline
\end{tabular}

The death of all microorganisms was $68.4 \%$, and mold fungi $18.6 \%$ (Table 7 ). It is probable that the irradiator had a greater inactivating effect not on fungi, but on bacterial representatives of the microbial association. However, in this association, the proportion of mold fungi before exposure to UV rays 
A.M. Abdullaeva et al., Preventive treatment of drying chamber..., RAP Conf. Proc., vol. 4, 2019, 206-211

for 60 minutes was $54 \%$, and after treatment this value, as in a 30-minute period, increased (by 1.2 times) due to a higher resistance of mold to radiation compared to bacteria. These data indicate that this mode of UV irradiation of the sausage drying chamber cannot definitively prevent the molding of products.

It was of interest to disinfect the drying chamber with smoked sausages with the OZUF device for 60 minutes. As can be seen from Table 4, the total number of microorganisms, on average, decreased 4.7 times, and mold fungi 4.2 times. It should be noted that the share of mold fungi in the total number of microorganisms before the air treatment was $53 \%$, and after disinfection $64 \%$, i.e. the increase in the amount of mold in the remaining association of microorganisms is again associated with a greater mortality of bacteria that are sensitive to two biocidal factors (UV and ozone). Concentration of all microorganisms and separately mold fungi in $1 \mathrm{~m}^{3}$ of air after a 60-minute disinfection turned out to be at a statistically equal level (78.7 and $76.2 \%$, respectively).

Data comparing the effectiveness of factors detrimental to microorganisms from exposure to OBN150 and OZUF in the air of the drying chamber for 60 minutes also statistically confirmed the effectiveness of the biocidal action of OZUF (Table 7).

In order to more intensively affect the microbes present in the drying chamber, a 90-minute treatment of the indoor air environment was carried out. As the data, obtained with the use of OBN-15O, in Tables 5-7 shows, the death of the total number of microorganisms present in the air of the drying chamber increased from $23.7 \%$ to $75.7 \%$ with the increase in exposure from 30 to 90 minutes, and for mold fungi from $9.7 \%$ to $56.3 \%$.

Table 5. The results of the study of the bactericidal and fungicidal properties of the ultraviolet irradiator OBN-150 after treatment of the air in the drying chamber for 90 minutes

\begin{tabular}{|c|c|c|c|c|}
\hline \multirow{2}{*}{\begin{tabular}{c} 
No of $\begin{array}{c}\text { the } \\
\text { Petri } \\
\text { dish }\end{array}$ \\
\cline { 2 - 5 }
\end{tabular}} & \multicolumn{3}{|c|}{ before treatment } & \multicolumn{2}{c|}{ after treatment } \\
\cline { 2 - 5 } & total microorganisms & of which molds & total microorganisms & of which molds \\
\hline 1 & $2.80 \times 10^{3}$ & $1.20 \times 10^{3}$ & $0.667 \times 10^{3}$ & $0.533 \times 10^{3}$ \\
\hline 2 & $2.67 \times 10^{3}$ & $1.20 \times 10^{3}$ & $0.667 \times 10^{3}$ & $0.533 \times 10^{3}$ \\
\hline 3 & $2.80 \times 10^{3}$ & $1.07 \times 10^{3}$ & $0.800 \times 10^{3}$ & $0.667 \times 10^{3}$ \\
\hline 4 & $2.53 \times 10^{3}$ & $1.33 \times 10^{3}$ & $0.533 \times 10^{3}$ & $0.533 \times 10^{3}$ \\
\hline 5 & $2.53 \times 10^{3}$ & $1.20 \times 10^{3}$ & $0.800 \times 10^{3}$ & $0.400 \times 10^{3}$ \\
\hline 6 & $2.67 \times 10^{3}$ & $1.07 \times 10^{3}$ & $0.667 \times 10^{3}$ & $0.533 \times 10^{3}$ \\
\hline 7 & $2.80 \times 10^{3}$ & $1.07 \times 10^{3}$ & $0.533 \times 10^{3}$ & $0.400 \times 10^{3}$ \\
\hline 8 & $2.40 \times 10^{3}$ & $1.20 \times 10^{3}$ & $0.533 \times 10^{3}$ & $0.400 \times 10^{3}$ \\
\hline 9 & $2.53 \times 10^{3}$ & $1.33 \times 10^{3}$ & $0.667 \times 10^{3}$ & $0.667 \times 10^{3}$ \\
\hline 10 & $2.53 \times 10^{3}$ & $1.20 \times 10^{3}$ & $0.533 \times 10^{3}$ & $0.533 \times 10^{3}$ \\
\hline $\mathrm{X} \pm \mathrm{m}$ & $(2.63 \pm 0.043) \times 10^{3}$ & $(1.19 \pm 0.029) \times 10^{3}$ & $(0.640 \pm 0.032) \times 10^{3}$ & $(0.520 \pm 0.030) \times 10^{3}$ \\
\hline $\mathrm{X} \pm \mathrm{I}_{95}$ & $(2.63 \pm 0.096) \times 10^{3}$ & $(1.19 \pm 0.065) \times 10^{3}$ & $(0.640 \pm 0.071) \times 10^{3}$ & $(0.520 \pm 0.067) \times 10^{3}$ \\
\hline
\end{tabular}

Table 6. The results of the study of the fungicidal and bactericidal properties of the ultraviolet irradiator and ozonizer OZUF after treatment of the air in the drying chamber for 90 minutes

\begin{tabular}{|c|c|c|c|c|}
\hline \multirow{2}{*}{\begin{tabular}{c} 
No of $\begin{array}{c}\text { the } \\
\text { Petri } \\
\text { dish }\end{array}$ \\
\cline { 2 - 5 }
\end{tabular}} & \multicolumn{3}{|c|}{ Defore treatment } & \multicolumn{2}{c|}{ after treatment } \\
\cline { 2 - 5 } & total microorganisms & of which molds & total microorganisms & of which molds \\
\hline 1 & $2.67 \times 10^{3}$ & $1.07 \times 10^{3}$ & $0.133 \times 10^{3}$ & $0.267 \times 10^{3}$ \\
\hline 2 & $2.53 \times 10^{3}$ & $1.33 \times 10^{3}$ & $0.267 \times 10^{3}$ & $0.133 \times 10^{3}$ \\
\hline 3 & $2.53 \times 10^{3}$ & $1.20 \times 10^{3}$ & $0.267 \times 10^{3}$ & $0.133 \times 10^{3}$ \\
\hline 4 & $2.80 \times 10^{3}$ & $1.33 \times 10^{3}$ & $0.400 \times 10^{3}$ & 0.00 \\
\hline 5 & $2.40 \times 10^{3}$ & $1.33^{3} \times 10^{3}$ & $0.267 \times 10^{3}$ & $0.267 \times 10^{3}$ \\
\hline 6 & $2.67 \times 10^{3}$ & $1.07 \times 10^{3}$ & $0.267 \times 10^{3}$ & $0.400 \times 10^{3}$ \\
\hline 7 & $2.80 \times 10^{3}$ & $1.20 \times 10^{3}$ & $0.133 \times 10^{3}$ & $0.133 \times 10^{3}$ \\
\hline 8 & $2.40 \times 10^{3}$ & $1.07 \times 10^{3}$ & $0.400 \times 10^{3}$ & $0.267 \times 10^{3}$ \\
\hline 9 & $2.53 \times 10^{3}$ & $1.33 \times 10^{3}$ & $0.267 \times 10^{3}$ & $0.133 \times 10^{3}$ \\
\hline 10 & $2.80 \times 10^{3}$ & $1.20 \times 10^{3}$ & $0.133 \times 10^{3}$ & $(0.187 \pm 0.031) \times 10^{3}$ \\
\hline $\mathrm{X} \pm \mathrm{m}$ & $(2.61 \pm 0.047) \times 10^{3}$ & $(1.21 \pm 0.034) \times 10^{3}$ & $(0.253 \pm 0.030) \times 10^{3}$ & $(0.187 \pm 0.070) \times 10^{3}$ \\
\hline $\mathrm{X} \pm \mathrm{I}_{95}$ & $(2.61 \pm 0.105) \times 10^{3}$ & $(1.21 \pm 0.076) \times 10^{3}$ & $(0.253 \pm 0.067) \times 10^{3}$ & \\
\hline
\end{tabular}

The combined irradiator-ozonizer OZUF turned out to be more effective. At the same time, the exposure provided an antibacterial effect with death from $67.7 \%$ to $90.3 \%$ and fungicidal effect $-35 \%$ to $84.5 \%$. These were the highest rates of disinfection of air drying chambers for sausages, confirmed statistically ( $\mathrm{p}<0.05$, Table 7).
It should be noted that additional studies of the organoleptic properties of smoked sausages did not change the specific properties of the product. Observations on the possibility of infection of raw smoked sausages for four months showed the effectiveness of such treatment. 
A.M. Abdullaeva et al., Preventive treatment of drying chamber..., RAP Conf. Proc., vol. 4, 2019, 206-211

Table 7. Comparative characteristics of bactericidal and

fungicidal properties of UV irradiators OBN-15O and OZUF in a drying chamber

\begin{tabular}{|c|c|c|c|c|c|c|c|c|c|c|}
\hline \multirow{3}{*}{ № } & \multirow{3}{*}{ Irradiator } & \multicolumn{4}{|c|}{$\begin{array}{l}\text { Numbers of colonies of microorganisms and molds } \\
\text { in } 1 \mathrm{~m}^{3} \text { of air, }\left(\mathrm{X}_{ \pm} \mathrm{I}_{95}\right) \times 1 \mathrm{O}^{3}, \mathrm{CFU} / \mathrm{m}^{3}\end{array}$} & \multirow{3}{*}{\begin{tabular}{|c|} 
Significanc \\
e of \\
differences \\
before and \\
after \\
treatment \\
$\frac{p}{p}$
\end{tabular}} & \multirow{2}{*}{\multicolumn{2}{|c|}{$\begin{array}{l}\text { Effectiveness of } \\
\text { irradiators, \% }\end{array}$}} & \multirow{2}{*}{\multicolumn{2}{|c|}{$\begin{array}{l}\text { Significance of } \\
\text { differences in } \\
\text { effectiveness } \\
\text { (p) }\end{array}$}} \\
\hline & & \multicolumn{2}{|c|}{ before treatment } & \multicolumn{2}{|c|}{ after treatment } & & & & & \\
\hline & & $\begin{array}{c}\text { total } \\
\text { microorganism } \\
\mathrm{s}\end{array}$ & molds & $\begin{array}{c}\text { total } \\
\text { microorganism } \\
\mathrm{s}\end{array}$ & molds & & $\begin{array}{c}\text { total } \\
\text { microorganism } \\
\mathrm{s}\end{array}$ & molds & $\begin{array}{c}\text { total } \\
\text { microorganism } \\
\mathrm{s}\end{array}$ & molds \\
\hline \multicolumn{11}{|c|}{ Treatment of the air for $30 \mathrm{~min}$} \\
\hline 1 & OBN-150 & $\begin{array}{c}2.47 \pm 0.100 \\
(2.37-2.57)\end{array}$ & $\begin{array}{c}0.827 \pm \\
0.069 \\
(0.758- \\
0.896) \\
\end{array}$ & $\begin{array}{c}1.88 \pm 0.078 \\
(1.802-1.958)\end{array}$ & \begin{tabular}{|c|}
$0.747 \pm 0.076$ \\
$(0.671-$ \\
$0.823)$ \\
\end{tabular} & $\frac{<0.05}{>0.05}$ & 23.9 & 9.7 & $\begin{array}{c}\text { p1-5 } \\
<0.05\end{array}$ & $\begin{array}{l}\mathrm{p} 1-5 \\
<0.05\end{array}$ \\
\hline 2 & OZUF & $\begin{array}{c}2.48 \pm 0.087 \\
(2.393-2.567\end{array}$ & $\begin{array}{c}0.800 \pm \\
0.074 \\
0.726- \\
0.874) \\
\end{array}$ & $\begin{array}{c}0.800 \pm 0.074 \\
(0.726-0.874)\end{array}$ & $\begin{array}{c}0.520 \pm 0.06 \\
7 \\
(0.453- \\
0.587) \\
\end{array}$ & \multirow[t]{2}{*}{$\frac{<0.05}{<0.05}$} & \multirow[t]{2}{*}{67.7} & \multirow[t]{2}{*}{35} & \multirow[t]{2}{*}{$\begin{array}{l}\text { p2-6 } \\
<0.05\end{array}$} & \multirow[t]{2}{*}{$\begin{array}{l}\mathrm{p} 2-6 \\
<0.05\end{array}$} \\
\hline & & $>0.05$ & $>0.05$ & $>0.05$ & $<0.05$ & & & & & \\
\hline \multicolumn{11}{|c|}{ Treatment of the air for $60 \mathrm{~min}$} \\
\hline 3 & $\mathrm{OBN}-15 \mathrm{O}$ & $\begin{array}{c}2.19 \pm 0.096 \\
(2.094-2.286)\end{array}$ & \begin{tabular}{|c|}
$1.13 \pm 0.105$ \\
$(1.025-$ \\
$1.235)$
\end{tabular} & $\begin{array}{c}0.693 \pm 0.091 \\
(0.602-0.784)\end{array}$ & $\begin{array}{c}0.920 \pm \\
0.098 \\
(0.822- \\
1.018)\end{array}$ & $\frac{<0.05}{\leq 0.05}$ & 68.4 & 18.6 & $\begin{array}{l}\text { p3-5 } \\
>0.05\end{array}$ & $\begin{array}{l}\text { p3-5 } \\
<0.05\end{array}$ \\
\hline 4 & OZUF & $\begin{array}{c}2.25 \pm 0.107 \\
(2.143-2.357)\end{array}$ & \begin{tabular}{|c|}
$1.29 \pm 0.08$ \\
5 \\
$(1.205-$ \\
$1.375)$ \\
\end{tabular} & $\begin{array}{c}0.480 \pm 0.087 \\
(0.393-0.567)\end{array}$ & $\begin{array}{c}0.307 \pm \\
0.042 \\
(0.265- \\
0.349) \\
\end{array}$ & \multirow[t]{2}{*}{$\frac{<0.05}{<0.05}$} & \multirow[t]{2}{*}{78.7} & \multirow[t]{2}{*}{76.2} & \multirow[t]{2}{*}{$\begin{array}{l}\mathrm{p} 4-6 \\
\leq 0.05\end{array}$} & \multirow[t]{2}{*}{$\begin{array}{l}\mathrm{p} 4-6 \\
<0.05\end{array}$} \\
\hline & & $>0.05$ & $>0.05$ & $<0.05$ & $<0.05$ & & & & & \\
\hline & \multicolumn{10}{|c|}{ Treatment of the air for $90 \mathrm{~min}$} \\
\hline 5 & $\mathrm{OBN}-15 \mathrm{O}$ & $\begin{array}{c}2.63 \pm 0.096 \\
(2.534-2.726)\end{array}$ & $\begin{array}{c}1.19 \pm \\
0.065 \\
(1.125- \\
1.255) \\
\end{array}$ & $\begin{array}{c}0.640 \pm 0.071 \\
(0.569-0.711)\end{array}$ & $\begin{array}{c}0.520 \pm \\
0.067 \\
(0.453- \\
0.587)\end{array}$ & $\frac{<0.05}{<0.05}$ & $75 \cdot 7$ & 56.3 & $\begin{array}{l}\mathrm{p} 5-6 \\
<0.05\end{array}$ & $\mid \begin{array}{c}\mathrm{p} 5-6 \\
<0.05\end{array}$ \\
\hline 6 & OZUF & $\begin{array}{c}2.61 \pm 0.105 \\
(2.505-2.715)\end{array}$ & \begin{tabular}{|c|}
$1.21 \pm 0.076$ \\
$(1.134-$ \\
$1.286)$ \\
\end{tabular} & $\begin{array}{c}0.253 \pm 0.067 \\
(0.186-0.320)\end{array}$ & \begin{tabular}{|c|}
$0.187 \pm 0.070$ \\
$(0.117-$ \\
$0.257)$ \\
\end{tabular} & $\frac{<0.05}{<0.05}$ & 90.3 & 84.5 & - & - \\
\hline & & $>0.05$ & $>0.05$ & $<0.05$ & $<0.05$ & & & & & \\
\hline
\end{tabular}

\section{CONCLUSION}

The data indicate the process of disinfection of the chambers for drying raw smoked sausages must be a combined action of UV rays and ozonation, with exposure times of at least 90 minutes.

\section{REFERENCES}

1. И. Г. Серегин, Д. В. Никитченко, А. М. Абдуллаева, "О болезнях пищевого происхождения," Вестник Российского университета дружбы народов. Серия: Агрономия и животноводство, но. 4, стр. $101-107,2015$.

(I. G. Seryogin, D. V. Nikitchenko, A. M. Abdullaeva, "About illness of foodborne diseases," Bull. Peoples' Friendship University of Russia. Series: Agronomy and animal industries, no. 4, pp. $101-107,2015$.

DOI: $10.22363 / 2312-797 \mathrm{X}-2015-4-101-107$

2. Н. А. Соколова, А. М. Абдуллаева, М. Н. Лощинин, Возбудители зооантропонозов, пищевых отравлений, порчи сыръя и продуктов животного происхождения, Москва, Россия: ДеЛи плюс, 2015. (N. A. Sokolova, A. M. Abdullaeva, M. N. Loshchinin, Pathogens of zooanthroponosis, food poisoning, spoilage of raw materials and products of animal origin, Moscow, Russia: DeLi plus, 2015) Retrieved from:

https://elibrary.ru/item.asp?id=24804630

Retrieved on: May 18, 2019
3. Ю. Г. Костенко, Руководство по санитарномикробиологическим основам и предупреждению рисков при производстве и хранении мясной продукции, Москва, Россия: Техносфера, 2015.

(Yu. G. Kostenko "Guidance on the sanitarymicrobiological basis and risk prevention in the production and storage of meat products," Moscow, Russia: Technosphere, 2015.) Retrieved from:

http://www.vniimp.ru/files/news/kostenko.pdf Retrieved on: Aug. 22, 2019

4. А. М. Абдуллаева, И. Г. Серегин, Л. Б. Леонтьев, Н. А. Соколова, М. Н. Лощинин, "О бактериальной безопасности мяса птицы,” Ветеринария сельскохозяйственных животных, но. 11, стр. 41 49, 2017.

(A. M. Abdullaeva, I. G. Seryogin, L. B. Leontyev, N. A. Sokolova, M. N. Loshchinin, "About bacterial safety of poultry meat," Vet. farm anim., no 11, pp. 41 49, 2017.)

Retrieved from:

https://elibrary.ru/item.asp?id $=36855580$

Retrieved on: Feb. 10, 2019

5. J. D. Greig, A. Ravel, "Analysis of foodborne outbreak data reported internationally for source attribution,"

Int. J. Food Microbiol., vol. 130, no. 2, pp. $77-87$, Mar. 2009.

DOI: 10.1016/j.ijfoodmicro.2008.12.031 PMid: 19178974

6. Л. С. Кузнецова, "Мицелиальные грибы инициаторы микробной порчи мясной продукции," Мясные технологии, но. 4, стр. 20 - 22, Апр. 2005. 
A.M. Abdullaeva et al., Preventive treatment of drying chamber..., RAP Conf. Proc., vol. 4, 2019, 206-211

(L. S. Kuznetsova, "Mycelial fungi - initiators of microbial spoilage of meat products," Meat technol., no. 4, pp. 20 - 22, Apr. 2005.)

Retrieved from:

http://www.meatbranch.com/magazine/archive/viewd oc/2005/4/50.html

Retrieved on: Feb. 12, 2019

7. А. Г. Снежко, М. И. Губанова, К. Г. Разумовского, “Эффективные составы для антимикробной обработки колбас," Мясная индустрия, но. 3, стр. $19-21,1999$.

(A. G. Snezhko, M. I. Gubanova, K. G. Razumovsky, "Antimicrobial protection of raw smoked sausages," Meat Ind., no 3, pp. 19 - 21, 1999.)

Retrieved from: http://meatind.ru/articles/1113/ Retrieved on: Mar. 12, 2019

8. А. М. Абдуллаева, И. Р. Смирнова, Е. В. Трохимец, А.А. Губанкова, "Микробиологический контроль полуфабрикатов из мяса индеек при холодильном хранении," Ветеринария, но. 8, стр. 49 - 53, 2017.

(A. M. Abdullaeva, I. R. Smirnova, E. V. Trochimetz, A. A. Gubankova, "Microbiological control of semifinished products from meat turkeys in the modified gas medium and shrink-stretch film during refrigerated storage," Vet. Sci., no. 8, pp. 49 - 53, 2017.)

Retrieved from:

https://elibrary.ru/item.asp?id=29800757

Retrieved on: Sep. 24, 2019
9. А. А. Прокопенко, Л. Ю. Юферев, “Эффективность применения уф облучателей - озонаторов "ОЗУФ" на объектах ветеринарного надзора," материалы Экология и сельскохозяйственная техника, Санкт Петербург, Россия, 2005, стр. $262-266$.

(A. A. Prokopenko, L. Yu. Yuferev, "Ultra-violet installations performance on the objects of veterinary inspection," in Proc. $4^{\text {th }}$ Int. Sci. Pract. Conf., Saint Petersburg, Russia, 2005, pp. 262 - 266.)

Retrieved from:

https://elibrary.ru/item.asp?id=21434608

Retrieved on: Jan. 1, 2019

10. Общая и санитарная микробиология с техникой микробиологических исследований: учебное пособие, А.С. Лабинской, Л. П. Блинковой, А. С. Ещиной, Под. Ред., 3-е изд., Санкт Петербург, Россия: Издательство Лань, 2019.

(General and sanitary microbiology with the technique of microbiological research. Tutorial, A. S. Labinskaya, L. P. Blinkova, A. S. Eshchina, Eds., $3^{\text {rd }}$ ed., Saint Petersburg, Russia: Lan publishers, 2019.) Retrieved from:

https://rus.logobook.ru/prod show.php?object uid=2 254526

Retrieved on: Oct. 27, 2019 